\title{
Unexpected Residents of the Qu'Appelle Valley
}

\author{
By E. M. CALLIN, Fort San, Sask.
}

On June 13, 1954 I had the good fortune to find my first nest of the Redstart when I watched a female building her nest in the crotch of a tree on the banks of a small creek bordering the west side of the town of Fort Qu'Appelle.

On June 25th I had the great pleasure of a visit from Dr. and Mrs. Stuart Houston of Yorkton. Visiting the nest we found the female incubating and the nest contained 4 eggs, Dr. Houston, with his boundless enthusiasm, was "well armed" with camera equipment and took several pictures, one of which is included here.

As most of the readers of the Blue Jay know, the Qu'Appelle Valley originates in the centre of the Transition Zone of Saskatchewan and, travelling in an easterly direction, bisects the eastern half of that zone. It has various favorable topographical features such as brushy hillsides, many fine groves of decidu- ous trees and a number of lakes along its route.

In addition to the usual Transition Zone species such as the Catbird, Brown Thrasher, and Oriole, many years of birding in the Qu'Appelle Valley have disclosed unexpected species to be resident here. Some of them are birds which do not normally nest south of the Canadian Zone - the evergreen belt much further to the north. A couple of them are birds of more southern distribution which have been attracted to the valley,

Although a considerable number of bird families are represented in the Qu'Appelle Valley, I am restricting the present list to those species which are of special interest. As my personal observations have been divided between the Round Lake area (north of Whitewood) and the Fort Qu'Appelle area (north-east of Regina) I will deal with each species in each area.

\section{Northern Birds and Birds of Local Distribution in the Transition Zone}

\section{Fort Qu'Appelle}

REDSTART

ORANGE-CROWNED

WARBLER

WATER-THRUSH

OVEN-BIRD

MOURNING-

WARBLER

CHESTNUT-SIDED

WARBLER

BLACK \& WHITE

WARBLER
Summer resident, regular, not common (Nest discovered).

Probable summer resident, regular, fairly common.

Summer resident, regular, fairly common (Nest discovered).

Migrant.

Migrant.

Not recorded.

Migrant.

\section{Round Lake}

Probable summer resident, regular, fairly common.

Probable summer resident, regular, not common.

Probable summer resiclent, regular and fairly common.

Probable summer resident, regular, not common.

Probable summer resident, irregular, uncommon.

Probable summer resident, regular, fairly common.

Probable summer resident, regular, fairly common. 


\section{Fort Qu'Appelle}

CANADIAN

WARBLER

ROSE-BREASTED

GROSBEAK

TOWHEE

CRESTED FLYCATCHER

WHITE-THROATED SPARROW

SLATE-COLORED JUNCO
Migrant.

Summer resident, regular, fairly common.

Summer resident, regular, common.

Not recorded

Migrant.

Migrant.

\section{Round Lake}

Probable summer resident, irregular, uncommon.

Summer resident, Regular, common, (Recorded as nesting by Fred G. Bard).

Summer resident, regular, common,

(Nest discovered).

Probable summer resident, regular, not common.

Probable summer resident, regular, not common.

Summer resident, regular, not common, (Nest discovered).

\section{Birds of more Southern Distribution}

Rare summer resident, (Nest discovered 1953 Blue Jay March, 1954, Pair certainly nested same location 1954).

Probable summer resident, regular, not common.
Not recorded, (Hypothetical record 10 miles south of the Valley May 31, 1954).

Probable summer resident, regular, not common.

\section{Winter Visitors}

Mrs. JOHN HUBBARD, Grenfell, Sask.

There have been few complaints about the weather this winter because it has been so mild; so mild in fact that most of our winter birds have failed to visit us. Instead of flocks of pine grosbeaks we have seen two and those back in November. We hear the chickadees off in the bush but they hardly ever come into the yard and Craig's piece of suet on the honeysuckle has not been touched.

Saturday, Jan. 15th, however, eight Bohemian waxwings did turn up to gorge on crabapples in the orchard. You would wonder how on earth any bird could eat frozen crabs but these birds have the beak for the job. It's strong and sharp as an awl. I'll accept no argument on this point. One fall at Indian Head I came on a flock of Cedar Waxwings (a smaller and yellower summer edition of the Bohemian Waxwing) feeding on rose hips. As they refused to pay any attention to me I picked a young one up. I don't know if it was mad or hungry but it bit my finger (I mean bit not peckedit simply opened its mouth and grabbed). Needless to say I dropped it quickly and I'll vouch for the sharpness of its beak.

These visitors had human traits too. Though there were three trees loaded with fruit and only eight birds they had to fight over the same crab. I imagine it helped to keep them warm.

The Bohemian Waxwing with its soft grey colouring tinged with rust, striking crest, yellow-banded tail and identifying red wax marks on wing is a welcome winter visitor. 